\title{
Students' Crisis in Nigerian Tertiary Educational Institutions: A Review of The Causes and Management Style
}

\author{
Ajibade David \\ Kogi State University, Anyigba, Nigeria
}

\section{Introduction}

Nigerian tertiary educational institutions are established with the aim of giving any student who enrols a very sound and qualitative education, to be able to function effectively in any environment in which he/she may find him/herself; so as to become more productive, self-fulfilling and attain self actualization (Federal Government of Nigeria,2004; Aluede, et al, 2005). In realization of all these important goals, the National Policy on Education (NPE) formulated in 1977, and reviewed in 2004 has as its policy: (a) the acquisition, development and inculcation of the proper value-orientation for the survival of the individual and society; (b) the development of the intellectual capacities of individuals to understand and appreciate their environment; (c) the acquisition of both physical and intellectual skills which will enable individuals to develop into useful members of the community; and (d) the acquisition of an objective view of the local and external environments (Federal Government of Nigeria, 2004).

These goals are expected to be pursued through: (i) teaching-imparting knowledge and skills (ii) research-discovery of knowledge (iii) dissemination-spreading existing and new information; (iv)service-fostering community service and professional training for the development of intermediate and high level manpower (Wokocha, 2003; NPE, 2004:31).The goals of tertiary education as enunciated above are crucial for national development. However, research by scholars such as Emaikwu and Eba (2001); Nwagwu (2005); and Okebukola (2006) have shown that many of the Nigerian tertiary educational institutions are finding it increasingly difficult to achieve the highlighted goals because of the problems confronting them. One of such is the problem of students' crises (Atteh, 1996; 
Onwurah, 2000; Alabi, 2002; Anifowoshe, 2004; Aluede, et al, 2005). Although Students' crisis is a global phenomenon which has ravaged countries like Peru, Columbia, Paraguay, Bolivia, Mexico, and across the length and breath of some African countries like Senegal, Cote d'ivore, Benin, in Western Africa, to Cameroon, Zaire and Gabon in Central African; and from Uganda, Sudan, Kenya, and Somali in Eastern Africa, to Zimbabwe and Zambia in Southern Africa (Wiseman, 1986; Nkinyangi, 1991; Balsvik, 1998) its occurrence in Nigeria in the recent past was on the high side. Students' crisis in Nigeria had occurred at different levels of time phases. These are at the colonial period (1940-1960), the immediate post independence and civil war era (1970-1986), and the economic crisis and adjustment (SAP) period (1986-1990s) (Onyenoru, 1996; Olamosu, 2000).

Based on the forgone, this paper is poised in finding answers to the following questions (i) what are the factors responsible for students' crises in Nigerian tertiary educational institutions in the recent past? (ii) what measures were adopted to manage students' crises in tertiary educational institutions in Nigeria? (iii) how effective were such measures?; and (iv) what are the alternative means of managing students crises in Nigeria tertiary educational institutions?. This paper is important because it will assist/help the principal officers of both old and newly established tertiary institutions (both public and private) to have an in-depth understanding of students' crises phenomenon and its management in Nigeria. The prevalence of students' crises in Nigeria in the recent past makes the paper apt. This is because the more that is known of students' crisis and its management, the better for the formulation of a realistic students crisis management strategy that will help to achieve peace in tertiary institutions and, thus, contribute to the achievement of the goals of tertiary education as specified in the National Policy on Education.

\section{Operational Definition of Terms:}

3.1 Management: The word 'management' has been defined variously by different scholars such as Stoner and Freeman (1989); Ogundele and Okonji (2004); Cole (2002); Abdulkareem (2000); Daft (2003); etc. According to Stoner and Freeman (1989), management is the art of getting things done through people. Ogundele and Okonji (2004) defined management as the functional process of accomplishing the goals of the organization through the help of others. Cole (2002) sees management as the collection of activities including planning, organizing, motivating and controlling. To Abdulkareem (2000) management means (i) a process (ii) a people (iii) a profession. According to him, management is a process by which limited 
resources are assembled and used to achieve predetermined goals. On the other hand, management as a people refers to the people that carry out the activities of management. As a special field of study, management is regarded as a profession. To Daft (2003), management is the attainment of organization goals in an effective and efficient manner through planning (defining/selecting goals and means to attain them), organizing (assigning responsibility for tasks accomplishment), leading (use of influence to motivate employees to achieve organizational goals), controlling (monitoring employees' activities, keeping organization on track toward achieving its goals, and making corrections as needed/necessary). From the foregoing, it is obvious that the focus of management is that it is concerned with the organization (arrangement) and efficient (prudent) utilization of the available resources in an establishment or institution or organization in order to achieve or accomplish specific goals. By and large, in this paper, management is taken to mean the act of handling and controlling disorderliness in an organization/institution.

3.2 Crisis: Crisis has been defined by different scholars such as Rosenthal, Charles and Hart (1989), Olamosu (2000); Schmid (2002); Best (2006), etc. For instance, Schmid (2002) defined crisis as sudden eruption of unexpected events caused by previous conflict. Best (2006) sees crisis as a degenerated stage of conflict, where threats to human security, intense violence characterized by fighting, death, injury, etc, occur. To Olamosu (2000), crisis is a state or condition in the life of a social unit, system, organization or society in which the existence of a problem assumes critical dimension to the extent that the survival or existence of the social system or structure is threatened. Rosenthal, Charles and Hart, (1989) defined crisis as a situation of severe threat to the basic structures or the fundamental values and norms of a social system which under time pressure and highly uncertain circumstances necessitates making critical decision. From these definitions, three elements are clear. These are (i) a threat to the organization/society/system (ii) the element of surprise, and (iii) a short decision time. However, in this paper, crisis means a situation of sudden rampage in an organization/institution which necessitates making vital decision in the shortest time possible.

3.3 Students: This refers to a group of people attending school such as universities, polytechnics, etc, with a view to acquiring knowledge and skills needed to function in their immediate environment and society at large. The general characteristics of students are as follows:

(i) Students are youth (Lipset 1971; Mohantey 1999; Okolocha, et al, 1999; Igbo 2000; and Yinusa 2005). The word, Youth has been defined variously by different scholars. According to Kenniston(1971), Youth refers to a period between 
adolescence and adulthood. Berger (1972) opines that youth cuts across age, pointing to culture as what really matters. According to him, any one who exhibits such qualities as spontaneity, impulsiveness, energy etc. is a youth. In Nigeria, anybody who is above the age of thirty is exempted from the compulsory National Youth Service Corps (NYSC) Scheme. He is simply not regarded as a youth (Albert 1997). Against this background, Yinusa's (2005) definition of Youth is accepted in this paper. He defined Youth as any one between the ages of eighteen and thirty.

(ii) Students are marginal men (Lipset, 1971). They are marginal between roles i.e between the security and status derived from their own families and the obligation to find a status of their own. Like all marginal men, they suffer from special insecurities and also have special capacities to see the imperfection of society. Studentship is a period in which the person is not burdened by financial or social responsibility. As observed by Mohantey (1999), students have more freedom than adults and they have relative freedom from parental and familial control, from financial responsibility and from outside work combined. Because of their freedom, students often take risks which other segments of the population can seldom take without concern for consequences.

(iii) Students often resent the authority of adults and rely more on their peers (Jupp, 1970; Cannavals, et al 1970). Lipset (1971) also observes that student stratum, as such creates a whole array of age-group symbols which set it apart from others in society and from adults in particular. These include unique patterns of personal appearance, peculiar mode of communication and special types of life. In their desire to demonstrate their rejection of the adult world, youth, and students among them in particular, repeatedly engage in forms of express behaviour noteworthy for their similarity (Smith, 1962; Sugarman, 1967).

(iv) Student communities often exhibit an idealistic orientation (Lipset, 1971). Lipset tersely characterizes university students as biologically adult, but socially irresponsible and idealistic. According to him, students evaluate things in absolute terms, right or wrong, good or bad, and just or unjust. German Sociologist Max Weber (1864-1920) in one of his lectures on "Politics as a Vocation" cited in Mohantey (1999:22) also observes that the youth have a tendency to follow a pure ethic of absolute end while mature men tend to espouse an ethic of responsibility. Students are more idealistic and less pragmatic; their contact with the articulated moral standards of their society is abstract. The overall idealistic orientation of students stimulates them to activism. 
(v) As long as students are on the campus, they are the non-established; they are without full time employment and are dependent on their families, educational institutions or on their own part time work for survival (Lipset, 1971). Lipset further observes that to the extent that students are the non-established, they are foot loose; they are not restrained by either economic or social obligation and have considerable energies to use up. From this stand point, their anti-system or anti establishment tendencies are not necessarily accidental but closely related to their economic and social status. Lipset (1971) also characterizes colleges/higher institutions as self contained communities. According to him, the existence of a large number of students at one location with more or less similar interests, and subject to a common environment inculcates in them a sense of community. Students from a special self contained community have a strong obligation not to betray one's peers, an equally strong inclination to question the legitimacy of adult authority, and make a remarkable capacity for immediate action and impromptu organization. The sense of community and cohesion according to Lipset enables the students to organize agitations and movement with ease and swiftness.

3.4 Students' Crises: is defined in this paper as the rampage made by students in pressing for their demands on certain issues with authorities of the various tertiary institutions of learning.

3.5 Management of Students' Crises: This refers to the act of handling and controlling students' disorderliness in an educational institution by management of such institutions

3.6 Management Style: It encompasses techniques/methods employed to deescalate students' rampage by authorities of such institutions in order to bring such crisis to its lowest ebb.

\section{Method and Materials}

Nigeria is constitutionally a federal republic comprising of 36 states and its Federal Capital Territory, Abuja. Nigeria lies between latitude $4010^{\prime}$ and $13^{\circ} 50^{\prime}$ and longitude $2^{0} 15^{\prime}$ and $14^{0} 45^{\prime} \mathrm{E}$ with the Republic of Benin bordering the country on the West, Niger on the North, and both Chad and Cameroun on the East, while the South is bordered by the Gulf of Guinea with an $800 \mathrm{~km}$ coastline (Nwa, 2003; Food and Agriculture Organization, 1995; Olagunju 2009; Ajibade and Owoyemi, 2012). The country is the tenth largest country in Africa with an approximately $923,768 \mathrm{~km}^{2}$ in total land area and is regarded as the most populous country on the Africa continent with more than 350 ethnic groups, a variety of social group (Otite, 
2006), and a population of $162,470,737$ million people (World Bank, 2011). This study focuses on Nigeria because of its high incidence of students crises in the recent past. As regard methodology adopted in this study, secondary source of data collection was used. Data were generated from textbooks, published and unpublished materials including the internet. The data generated were first of all summarized and then content analyzed.

\section{Historical Evolution and Development of Tertiary Educational Institutions in Nigeria}

The history of higher education in Nigeria began with the establishment of Yaba Higher College in 1934, to provide middle-level manpower for government and private sector (Wokocha, 2003). The college came into being only after a lot of agitations and demands by the National Congress of British West Africa (NCBWA) led by Casely Hayford, a lawyer from Accra, Ghana, the headquarters of the organization (Aminigo, 2003). However, right from the inception of the college, the generality of educated Nigerians especially those residents in Lagos, condemned the quality of programmes which the Yaba Higher College offered at that time (Nwideeduh, 2003). They viewed the institution as an inferior one designed by the colonialists to produce Nigerians who would always be in subordinate positions to the colonial masters; besides, the Yaba Higher College was also seen to be suffering immensely from many disabilities such as the restriction of number of students to be admitted, the stringency of admission requirements, the imposition of the choice of courses and the high rate of drop-outs of students (Wokocha, 2003). In line with this, therefore, in 1943 the colonial government sets up the Elliot Commission to examine the possibility of establishing university colleges in Nigeria, the Gold Coast (Ghana) and Sierra Leone. The commission report suggested the establishment of the University College, Ibadan, which later came into being in 1948 (National Teachers' Institute, 2005).

By 1960, the University College, Ibadan which was established to award academic degree of the University of London, had established itself as a reputable institution of higher learning; it was also making a great contribution to manpower needs of Nigeria (National Teachers' Institute, 2005). But the need for a larger output of University graduates was increasingly felt and commonly expressed. For example, as far back as 1955, there were serious thoughts and attempts to establish another University (Jubril, 2003). University College, Ibadan was criticized for its low annual intake conditioned by the residential nature of the college, its continual dependence on the University of London, limited number of disciplines such as 
engineering, architecture, law, business and accounting been offered by the college. It was also criticized for not responding to public criticisms, demands or needs. There were also criticisms of its constitution, policies and administration, its flagrant and subtle attempts at racial discrimination (Wokocha, 2003).

Partly because of these criticisms, the Federal Minister of Education, on behalf of the Federal and Regional Governments, set up the Ashby Commission in 1959, to advise government on the higher education needs of Nigeria for its first two decades (Jubril, 2003; Junaid, 2003; Wokocha, 2003). The implementation of the recommendation of the commission culminated in the establishment of four new universities at Nsukka in 1960; Ife (now Obafemi Awolowo University) in 1962; Zaria in 1962; Lagos in 1962; while the University College, Ibadan became independent of London university in 1962 and also became a full-fledged University of Ibadan (Jubril, 2003).

By 1962, there were only three regions in Nigeria. Thus, each of the regions had a University. With the creation of the Mid-Western Region in 1963, the yearning for a regional higher institution was set in motion; and the Mid-Western Institute of Technology, which was established in 1970, later became the University of Benin (Wokocha, 2003).With the oil boom in Nigeria in the 1970s, the Federal Military Government under the leadership of retired General Yakubu Gowon established seven new universities in 1975, viz, Calabar, Port-Harcourt, Ilorin, Jos, Maiduguri, Sokoto and Kano (Nwideeduh, 2003). It was therefore logical to say that all the twelve states in the federation then had at least a university located within its borders (Kosemani, 1982).

The creation of more states in the country in 1976 by the Federal Military Government under late General Murtala Mohammed necessitated the need for the geopolitical balancing in establishing Federal Universities in all the nineteen states. This decision informed the birth of the Universities of Technology at Owerri (Imo State), Bauchi (Bauchi State), Makurdi (Benue State) in 1980, Minna (Niger State) and Abeokuta (Ogun State) in 1982. In 1987, the Universities of Technology, Makurdi and Abeokuta, became specialized Universities of Agriculture, while the University of Abuja was opened in 1988 (Nwideeduh, 2003). On their own part, state governments also joined in the establishment of Universities and other tertiary institutions like polytechnics, colleges of education, etc, to satisfy the higher education needs of their people (National Teachers' Institute, 2005; Adeyemi, 2009).

In 1999, Nigeria's entire tertiary education system (Federal, State and Private) comprised of 211 institutions: 16 Federal Universities (Conventional), 4 Federal 
Universities of Technology, 3 Federal Universities of Agriculture, 1 National Open University 4 National Centers for Specialized Tertiary Institution, 16 State Universities, 7 Private Universities, 1 Military University, 17 Federal Polytechnics, 27 State Polytechnics; 7 Private Polytechnics, 22 Federal Colleges of Education, 38 State Colleges of Education, 36 Colleges of Agriculture, and 12 Specialized Training Institutes (Williams, et al, 2003).

In the year 2011, the number of tertiary institutions in Nigeria rose to 363, that is 25 Federal Universities (Conventional), 3 Universities of Agriculture, 6 Universities of Technology, 1 National Open University, 4 National Centre for Specialized Tertiary Institutions, 29 State Universities(conventional), 5 State Universities of Technology, 40 Private Universities, 1 Military University, 23 Federal Polytechnics, 22 Federal Monotechnics, 6 College of Health Sciences, 40 State Polytechnics, 17 State Monotechnics, 18 Private Polytechnics, 2 Private Monotechnics, 12 Federal Colleges of Education (Regular), 8 Federal Colleges of Education (Technical), 1 Federal College of Education (Special), 44 State Colleges of Education (Regular), 3 State Colleges of Education (Technical), 41 Private Colleges of Education, and 12 Specialized Training Institutes (Joint Admission and Matriculation Board Brochure, 2011).

The increase in the number of tertiary educational institutions in Nigeria could be partly attributed to the Obansanjo (1999-2007) government policy of deregulation (which was also adopted by his successors late Alhaji Umar Musa Yar'adua and the incumbent, President Good Luck Jonathan) in the educational sector. The Federal and State Governments were previously the only bodies licensed to operate tertiary institutions in Nigeria. With this new policy, licenses were granted to individuals, corporate and religious bodies to establish private universities, polytechnics and colleges of education. The astronomical rise also bears testimony to the country's absolute faith in the power of education to transform the nation from her present status of a developing country to a fully developed one. This trend is still continuing.

\section{Incidence of Student's Crises in Nigeria}

The table below shows some of the cases of student's crises in Nigeria Table 1: Some Cases of Students Crises in Nigerian Tertiary Educational Institutions

\begin{tabular}{|l|l|l|l|}
\hline Year & Institutions & $\begin{array}{l}\text { Stated Causes of } \\
\text { Unrest }\end{array}$ & Outcomes of the crises \\
\hline 1960 & $\begin{array}{l}\text { Many Nigerian } \\
\text { University }\end{array}$ & $\begin{array}{l}\text { Signing of Military } \\
\text { pact by the Federal } \\
\text { Government of }\end{array}$ & Cancellation of the pact \\
\hline
\end{tabular}




\begin{tabular}{|c|c|c|c|}
\hline & & $\begin{array}{l}\text { Nigeria with the } \\
\text { United Kingdom }\end{array}$ & \\
\hline 1981 & $\begin{array}{l}\text { Ahmadu Bello } \\
\text { University, Zaria }\end{array}$ & $\begin{array}{l}\text { Religion and against } \\
\text { Vice Chancellor over } \\
\text { alleged Rice deal }\end{array}$ & $\begin{array}{l}\text { Student died and Vice- } \\
\text { Chancellor dismissed. }\end{array}$ \\
\hline 1984 & $\begin{array}{l}\text { Many Nigerian } \\
\text { tertiary institutions }\end{array}$ & $\begin{array}{l}\text { Proposed introduction } \\
\text { of tuition fees and the } \\
\text { scrapping }\end{array}$ & $\begin{array}{l}\text { Many Universities were } \\
\text { closed down for } \\
\text { months }\end{array}$ \\
\hline 1986 & $\begin{array}{l}\text { Many Universities in } \\
\text { Nigeria }\end{array}$ & $\begin{array}{l}\text { High handedness of } \\
\text { the Vice-Chancellor of } \\
\text { Ahmadu Bello } \\
\text { University, Zaria }\end{array}$ & $\begin{array}{l}\text { Most Universities in Nigeria } \\
\text { were closed down for months. } \\
\text { While several students were } \\
\text { expelled. }\end{array}$ \\
\hline 1988 & $\begin{array}{l}\text { Many Nigerian } \\
\text { Universities }\end{array}$ & $\begin{array}{l}\text { Removal of subsidy } \\
\text { from petroleum and } \\
\text { allied products }\end{array}$ & $\begin{array}{l}\text { Many schools were closed for } \\
\text { a period of } \\
\text { Six months. }\end{array}$ \\
\hline 1989 & $\begin{array}{l}\text { Several schools In } \\
\text { many parts of Nigeria }\end{array}$ & $\begin{array}{l}\text { Introduction of } \\
\text { Structural Adjustment } \\
\text { Program (SAP) by the } \\
\text { Federal Government }\end{array}$ & $\begin{array}{l}\text { Improved conditions of } \\
\text { service for workers, } \\
\text { closure of several institution } \\
\text { for about six months. Many } \\
\text { students lost their lives during } \\
\text { the Protest as a result of open } \\
\text { shooting by Police/Army }\end{array}$ \\
\hline 1992 & $\begin{array}{l}\text { Many Universities in } \\
\text { Nigeria }\end{array}$ & $\begin{array}{l}\text { Deregulations of } \\
\text { Nigerian currency and } \\
\text { mounting hardship }\end{array}$ & $\begin{array}{l}\text { Several students died, } \\
\text { workers' conditions of } \\
\text { service were improved, while } \\
\text { several schools were closed } \\
\text { for months }\end{array}$ \\
\hline 1998 & $\begin{array}{l}\text { Ambrose Alli Uni., } \\
\text { Ekpoma, Nigeria }\end{array}$ & Cult Activities & $\begin{array}{l}\text { Violence leading to the death } \\
\text { of many students }\end{array}$ \\
\hline 2003 & $\begin{array}{l}\text { Many universities in } \\
\text { Nigeria }\end{array}$ & $\begin{array}{l}\text { Increase in the prices } \\
\text { of petroleum products }\end{array}$ & $\begin{array}{l}\text { Peaceful in some campuses } \\
\text { violent in others }\end{array}$ \\
\hline $005^{2}$ & $\begin{array}{l}\text { Olabisi onabanjo } \\
\text { University (OOU) } \\
\text { Ago-Iwoye }\end{array}$ & $\begin{array}{l}\text { Killing of Students by } \\
\text { the members of the } \\
\text { host community }\end{array}$ & $\begin{array}{l}50 \text { vehicles were completely } \\
\text { vandalized and the palace of } \\
\text { the monarch of the town was } \\
\text { burnt. }\end{array}$ \\
\hline 2005 & $\begin{array}{l}\text { OOU College of } \\
\text { Agricultural Science, } \\
\text { Ayetoro }\end{array}$ & $\begin{array}{l}\text { Killing of Student by } \\
\text { the police }\end{array}$ & $\begin{array}{l}\text { Divisional police headquarter } \\
\text { as well as Wema Bank branch } \\
\text { were completely burnt. }\end{array}$ \\
\hline
\end{tabular}

Source: (1) Aluede, O.,Jimoh,B.,Agwinede,B.O.,and Omoregie,E(2005) "Student Unrest in Nigerian Universities: Looking Back and Forward" Journal of Social Science, 10,1: 17-22. (2) The Punch Newspaper June 17, 2005; The Guardian Newspaper June 17, 2005.

\section{Sources of Students' Crises in Nigeria Tertiary Institutions}


Scholars differed in their explanations of the sources of students' crises. One study, for instance, traced the sources of the phenomenon to five related factors associated with the wider Nigerian crises. These are authoritarian governance arising from the erosion of institutional autonomy; infrastructural collapse and social distortion due to poor funding; poor motivation of staff who have a major obligation for the moral character and well-being of the students; the impact of the wider moral crisis on the tertiary institutions staff and students; and the precarious socio-psychological mental state of students as youths in social change and their consequent disposition to immediacy (Onyenoru, 1996). Some other studies locate the crises in factors such as declining economic conditions which have affected students' lives and studies, poor communication between institutions authorities and students, poor funding of tertiary institutions, insufficient and aging of social amenities and academic facilities, socialization influence, brain drain and poor attention to students; ideological and political reasons, secret cult activities, etc (Ojo,1995; Olamosu, 2000; Salami, 2000; Ofordile, 2001; Agbola, et al, 2001; Aderinto, 2002; William, et al, 2003; Adisa, Okosi and Aderinto, 2004; Aluede, et al, 2005; Adeyemi, 2009). There is, however, a general acknowledgement of the inherent volatility and fluidity of the students' crisis phenomena.

Theoretically, the sources of students' crises can be explained within the framework of anomie theory propounded by Merton (1957) and Behavioral leadership approach formulated by behavioral scholars such as Blanke and Manton (1964); Havey (1974); and Liket (1961). Merton borrowed Durkheim's concept of anomie to form his own theory. However, his theory differ somewhat from Durkheim's in that, Merton argued that the real problem in the modern society is not created by a sudden social change, as Durkheim proposed, but rather by a social structure that holds out the same goals to all its members without giving them equal means to achieve them. It is this lack of integration between what the culture calls for and what the structure permits that causes the breakdown of the normative system. Merton notes that there are certain goals which are strongly emphasized by society (i.e. acquisition of power, wealth, etc) and certain means (i.e. education, hardwork, unlimited job opportunity, etc) were equally emphasized to reach the goals. However, not everyone according to Merton has equal access to the legitimate means to attain those goals.

Merton presents five ways in which individuals denied access to socially approved goals and means may adapt to the strain-conformity, innovation, ritualism, retreatism and rebellion. The conformist continues to accept both the goals as well as the prescribed means for achieving those goals. Individuals who adapt through innovation reject the means (hardwork, etc) and design alternative means/ways (burglary, fraud, robbery, embezzlement or a host of other crimes) to attain the 
goals (wealth, power, etc) prescribed by society, which he/she continues to uphold/accept. In ritualism, individual's abandon/reject the prescribed goals (wealth, power, etc) emphasized by the society but continues to uphold the culturally prescribed means (hardwork, etc). Retreatism is the adaptation of people who give up both the goals (can't make it) and the means (why try?) and retreat into the world of alcoholism and drug addiction. They have internalized the value system and therefore under internal pressure not to innovate. The final adaptation, rebellion, occurs when the cultural goals and the legitimate means are rejected. Individuals create their own goals (i.e. get rid of establishment) and their own means (revolutionary activities i.e. physical violence-violent demonstration/riot).

Students' crises in Nigeria can be hung on the fifth adaptation-Rebellion. The strong cultural emphasis on success goals in Nigeria is not matched by an equally approved means. Everyone is socialized to aspire towards high achievement and success. These successes are expected to be achieved through legitimate educational and economic endeavours. However, it is obvious that the Nigerian economic and educational systems subject students to diverse strain and stress individually and as a group. For instance, many tertiary educational institutions in Nigeria lack basic amenities like functional laboratory, well equipped library, sports equipment and adequate hostel with functional facilities like water, light, etc, necessary for successful academic enterprises. Again, the spectre of unemployment, underemployment and inflation haunts many students in Nigeria. Under this condition, students are apt to question and challenge the legitimacy of the social, economic, institutional and political arrangement producing such inimical conditions.

In the main, Merton's strain theory explained the societal/structural based factors responsible for students crises but does not totally/completely explain the institutional-based factors most especially the nature of leadership in an educational institutions which can equally be a source of students crises. Hence the use of Behavioural Leadership Approaches. The behavioural leadership approach focuses attention on the actual behaviour and actions as opposed to traits or characteristics of leaders. Thus, the leaders' behaviour that is observable by others makes up his/her leadership styles. Three types of leadership styles had been identified by behavioralist scholars such as Blanke and Manton, 1964; Havey, 1974; Liket 1961. These leadership styles are Autocratic/Authoritarian, Democratic, and Laissez-Faire.

Autocratic/Authoritarian leadership style is characterized by one-way communication in which the leader defines the role of the individual or group and provide the what, how, when, and where to do the task. The institution administrator with 
autocratic leadership style often makes decision for its staff and students. $\mathrm{He} / \mathrm{she}$ talks more than he/she would listen and emphasizes the needs of the institution more than anything else. He/she believes that the end justifies the means. The democratic leadership style on its own has to do with participative management. It is a style that is characterized by extensive use of the group decision method and in which each person is given wider opportunity to exercise discretion for overall good. The democratic leaders/administrators often enlist the interests of staff and students and often works through appointed committees. Whenever they call staff meeting, they allow every member to fully participate in the discussion and decisions. Praises and criticism are given whenever occasion call for them. The leaders are accessible to both staff and students while the channel of communication is opened to all members of staff.

Laissez-faire leader on the other hand uses his/her power very little, if at all, giving subordinates a high degree of independence, or free rein, in their operations. Such leader depends largely on subordinates to set their own goals and means of achieving them, and they perceive their role as one of facilitating the operations of followers by furnishing them information and acting primarily as a contact with the groups' external environment. This style of leadership encourages too much individual efforts and thus breeds selfish tendencies. It also brings about unbridled freedom, which may be abused, and eventually turn educational institution for instance, into places of permissiveness, disorderliness and lawlessness.

Most of the heads of tertiary institutions in Nigerian adopts authoritarian/autocratic leadership style by not listening to the yearning and aspiration of the students, lackadaisical in terms of provision of amenities such as water, health facilities, etc. These again act as strain on the students' actualization of their dream or goals which invariably result to crises situation in most of the tertiary institutions. For example, University of Abuja students demonstrated recently over non-provision of adequate laboratory for medical and engineering students (Daily Trust, April 3, 2012).

\section{Crisis Management Model}

Conflict management scholars such as Thomas (1976); Tosi, Rizzo, and Carroll (1986); De Bono (2005); Best (2006); etc have provided four methods of managing crises. These are: the use of violence and coercion, bargaining and negotiation, problem solving and mediation. Violence/coercion (in physical or psychological form) is a win or lose style of managing crisis. It is asserting one's view point (through the use of coercive state apparatus) at the expense of another. Negotiation 
and Bargaining is a way of dealing with crisis, particularly when the parties in crises have relatively equal power and mutually independent goals. It is based on the belief that a middle route should be found to resolve the crisis situation, with concern for personal/group/organizational goals as well as relationship. In the process of negotiation, there are gains and losses for each party. Problem solvingThis involves identifying causes of crises and removing such so as to make the situation normal again. Mediation-This is the involvement of third party -binding (legal system i.e the use of court and litigation processes), non-binding (the use of traditional rulers/opinion leaders) and non-governmental organization (NGOs)/associations to settle differences/dispute between parties in crises.

\section{Measures adopted by Authorities of Tertiary Institutions in Curbing Students Crises}

Scholars such as Ogunyemi (1994); Omole (1995); Onyenoru (1996); Onwurah (2000); Alabi (2002) have written on the management of students' crises in Nigeria. According to these scholars, efforts at managing students' crises by the concerned authorities (government and institutions) often take the form of immediate closure of institutions with an ultimatum instructing students to vacate their halls of residence and premises; suspension or dissolution of students' unions and their executives. And when the crises have a national impact, the government often reacts by proscribing the Students' Union Organization at the national level. Other strategies mentioned by these scholars include rustication or outright expulsion of student leaders and the use of security forces like the police/army to maintain law and order in the affected institution.

During General Ibrahim Babangida's Military Administration (1985-1993), the Students' Union Activities (Control and Regulation) Decree No 47 was promulgated in 1989 which made national students union (NANS) and the unions in the respective universities subject to proscription if found to act contrary to national interest, security, public safety, morality and health. The decree also stipulated severe penalties for offenders including N500, 000 fines, or a five-year term of imprisonment, or both for persons convicted by the Special Tribunal set up under the decree (Onyenoru, 1996; Ogunyemi, 1994; Alabi, 2002). The Babangida administration also introduced voluntary unionism in the tertiary institutions which made it discretionary for students to belong to the students' unions-the National Association of Nigerian Students (NANS). That act was aimed at stifling the students' unions by reducing their membership and finances and frustrates their activities (Onyenoru, 1996). 


\section{An Assessment of the Effectiveness of the Measures Adopted in Curbing Students' Crises}

Those measures as emphasized above are regulatory and repressive in nature. And rather than helped to mitigate the problem of students' crises, such measures had only further aggravated the phenomenon. For instance, Anifowoshe (2004) observed that the use of police, by the authorities (state and institution) have led to the escalation of violence on the campuses. By law, the police have the right to use some force, if necessary, to make an arrest, to keep peace or maintain public order. More often than not, the sight of the police by protesting students, according to him, often ignites campus disturbances rather than reducing the likelihood of violence. Anifowoshe further argued that the frequent imposition of ban on student unionism by the government or university administration often triggers-off agitation resulting in frequent confrontational behavior with both the government and its agents and institutions' authorities. Students' union organization, according to Anifowoshe, is seen by the students as the only potent instrument of bargaining with both the government and institutions authorities for meeting group demands. If such avenue is blocked through proscription or ban, students often take the laws into their hands, including the use of violence as the only avenue for pressing for their demand.

Best (2006) in his own contribution contends that the intervention of the police and other law enforcement agents often calls for the use of extra-ordinary measure, including force, to restore law and order. This, to him, always leads to human rights violations of various dimensions as African Military and Police Services sometimes display high-handedness, excesses and unprofessional conduct in crisis control situation.

Alemika and Chukwuma (2000) equally argued that the use of police to suppress socio-economic discontents among workers, students and disempowered groups in society often results in violence by and against police. Police violence has been discussed in literature in terms of the individual, situational and organizational factors. The individual approach tries to explain police use of force in terms of the characteristics of the officers, the situational approach seeks to account for police use of force by relating it to the specific characteristics of the situation in which police encounter citizens, while the organizational approach sees the use of force as a product of the organizational setting or some aspects of the setting within which it occurs (Friedrich, 1983). Thus police violence in terms of the pathology of officers emphasizes the deficiency inherent in their education, social relation skill, 
as well as psychological and moral quality. In contrast, the situational approach focuses on the context of police-citizen contacts. The organizational approach emphasizes the role of leadership quality, of training and facilities, departmental rules, discipline and reward system, internal control within police departments as well as the degree to which the police are accountable to the public (Friedrich, 1983; Alemika and Chukwuma, 2000). These factors are, no doubt, important. In Nigeria, the average policeman is inadequately educated for the role he/she is expected to play. Further, he is inadequately trained for the police work; he is poorly remunerated and equipped and is resented by the public. Consequently, he is prone to react to students' crises cynically and aggressively.

The use of police to scuttle, disperses, and breaks students crises had led to the killing and maiming of many students. For instance, in 1971, one student, Kunle Adepeju, was killed by a police bullet, while eleven others were injured during a violent students' demonstration against the University of Ibadan authority. Also in 1978, four students were killed at the University of Lagos and seven at the Ahmadu Bello University, Zaria, during the nation-wide anti-state violent riots which were popularly described as "ALI MUST GO". In 1981, seven students were killed at the University of Ife during an anti-government demonstration which started peacefully but was dispersed by the police mid way, contrary to an initial understanding between the police and the students' union leaders prior to the on set of the students' long trek to the palace of the Oni of Ife (Sanda, 1982; Aluede, et al, 2005). Similarly, the result of armed intervention at the Ahmadu Bello University, Zaria students' crisis of 1986 was the loss of fifteen students' lives; the revolt then spread to other federal universities in Nigeria. Demonstration at Universities in Nigeria in May/June 1989 cost twenty-two students' lives according to official estimate, while unofficial sources estimated the number of deaths to be nearly one hundred (Balsvik, 1988; Aluede, et al, 2005).

Taiwo (2004) in his work titled "An appraisal of the use of threat/violence in resolving students crises in Nigerian Universities" argued that the closure of institutions as a method of arresting violent situations entails a disruption of academic programme, the results of which are inadequate work, poor performance and outright failure. In the same vein, Aluede and Imhanlahimi (2004) in their work,titled "Towards a psychological frame for explicating student's unrest in Nigerian Universities" contend that incessant closure of schools whenever there is demonstration has an adverse effect on the scope and curriculum of programmes offered in Nigerian universities. Further implication of using regulatory and intimidatory methods of crisis management by authorities is aptly summarized by Keller (1983:274) thus: when a state relies on the use of intimidatory or regulatory techniques, it suggests the image of a state which is low in legitimacy and 
desperately struggling to survive, but also can do more to threaten state coherence than to aid it.

\section{A Suggestion for Alternative Means of Managing Students Crises in Nigeria}

Since the measures adopted by the authorities of tertiary educational institutions in managing student's crises were found ineffective, there is the need to suggest alternative measure and the measure suggested in this paper is the democratic style of crisis management. And this entails the use of dialogue with students by tertiary institutions authorities, involvement of student in decision making, bridging of communication gap between students and institutions authorities as well as setting up of welfare committee to seek out student problems or challenges. It is believe that this measure if properly used will help to avert student crises in the Nigerian tertiary educational institutions

\section{Conclusion}

This paper reviewed students' crisis generally and identified the factors responsible for its occurrence and the management style adopted by the individuals and groups involved in the administration of tertiary institutions system. Factors such as authoritarian governance arising from the erosion of institutional autonomy infrastructural collapse and social distortion due to poor funding, poor remuneration of staff who have a major obligation for the moral character and well-being of the students, decline economic conditions which have affected students lives and studies poor communication between institutions authorities and students, social cult activities etc, more identified as the services of the students crises. However, in managing the phenomenon, diverse management styles ranging from the immediate closure of institutions, suspension or dissolution of students union government and their executives, rustication or outright expulsion of student leaders, to the use of security agencies such as police/army were adopted by the authorities of these institutions. Such management styles are, however, regulatory, assertive and reactive and rather than helped to bring the crises under effective control, it was found to always aggravates the phenomenon. Based on this therefore, it is hereby suggested that a proactive and democratic styles of crises management should be adopted by the individuals and groups involved in tertiary institution system.

\section{References and notes:}


1. Abdulkareem A.Y(2000) "Management: Concept, Principles and Functions" in Femi Durosaro and Segun Ogunsaju (eds) The Craft of Educational Management, Ilorin: Haytee Press and Publishing Co. Nig. Ltd. Pp 15-28.

2. Aderinto, A.A (2002) "The Concept of Social Problem" In Isiugo-Abanihe U.C, Isamah, A.N., and Adesina J.O. (eds) Currents and Perspective in Sociology. Lagos: Malthouse Press Pp. 335-348.

3. Adeyemi, T.O (2009) "Causes, Consequences and Control of Students' Crises in Public and Private Universities in Nigeria" Educational Research and Review, Vol. 4, No. 4: 156-163, April.

4. Adisa, J., Okosi A. and Aderinto, A (2004) "Students' Unrest and University Governance in Nigeria: Causes, Patterns, Impacts and Prognosis". Research Report Submitted to the Social Science Council of Nigeria.

5. Agbola, T., Olatubara, O, and Alabi, M (2001) Student On-Campus Housing at Bursting Point: A Case Study of the University of Ibadan, Ibadan: IFRA/African Builders.

6. Alabi, A.O. Akanbi, G.O. and Owoade,A (2002) History of Education: A Course Test for the Undergraduates; Ibadan: Kingdave Publishers.

7. Alemika, E.E and Chukwuma, I (2000) Police-Community Violence in Nigeria, Lagos: Centre for Law Enforcement Education.

8. Aluede, O. and Imhanlahimi. E (2004) Towards a Psychological Frame for Explicating Students Unrest in Nigerian University. Retrieved from Google 20/10/2007.

9. Aluede, O.,Jimoh,B.,Agwinede,B.O.,and Omoregie,E(2005) "Student Unrest in Nigerian Universities: Looking Back and Forward" Journal of Social Science, 10,1: $17-22$.

10. Albert, O (1997) "Kano: Religious Fundamentalism and Violence" in Herault (ed) Youth, Street Culture and Urban Violence in Africa. Ibadan: Institute of African Studies.

11. Amingo, I (2003) "Higher Education and Development in Nigeria" in Sam. B. Nwideeduh (ed)Trends and Issues in Managing Universities in Nigeria, Owerri: Springfield Publisher Pp. 89-105.

12. Anifowoshe, R (2004) “Campus Violence: An Overview of Students' Protest in Nigeria's Tertiary Institution" In Lai Olurode and Omololu Soyombo (eds) Reading in Campus Violence, Lagos; Johnwest Publication Ltd. Pp. 66-85.

13. Atteh,S .O(1996) "The Crisis in Higher Education in Africa" A Journal of Opinion(African Studies Association) Vol. 24,No1:36-42 (winter-spring)

14. Balsvik, R (1998) "Student Protest-University and State in Africa 1960-1995". Forum for Development Studies. N0.2.

15. Best, S.G (2006) "The Method of Conflict Resolution and Transformation" in Shedrack Gaya Best (ed) Introduction to Peace and Conflict Studies in West Africa. Ibadan: Spectrum Book Ltd. Pp. 93-115.

16. Bilton T., Bonnet, K., Jones, P., Stanworth, M., Sheard, K., and Webster, A (1981) Introductory Sociology. London: Macmillan.

17. Blake R.R and Monton, J.S (1964) The Managerial Grid, Houston TX: Gulf

18. Cannavals, F. Scarr, H. and Pepitone, A (1970) "Deindividuation in Small Group: Further Evidence", Journal of Personality and Social Psychology. 16, 141-147 
19. Cole, G.H (2002) "Management: Theory and Practice (5th ed), London: Continum

20. De Bono, E. (1985) Conflicts: A Better Way to Resolve Them, London: Harrap.

21. Draft, R.L (2003) Management, 6th edition, USA: Thomson South - Western Learning Press.

22. Emaikwu, S; and Eba, A (2001) "Examination Malpractice in Tertiary Institution: Implication and the Way Forward" in Akubue, A.U. and Enyi, D (eds) Crises and Challenges in Higher Education in Developing Countries, Ibadan: Wisdom Publishers.

23. Federal Government of Nigeria (2004) National Policy on Education (4th Edition). Yaba, Lagos: NERDC Press Pg 30

24. Federal Government of Nigeria (2009) Federal Republic of Nigeria Official Gazette Vol. 96, No 2.

25. Friedrich, R.J (1983) "Police Use of Force: Individuals, Situations, and Organizations" in Cob, Klockars (ed) Thinking about Police: Contemporary Readings, New York: McGraw-Hill Book Co. P. 311

26. Igbo E. U. M (2003) "Nigerian Youths and Changing Cultural Values in the Name of Development: The Igbo Case". Nnamdi Azikwe University, Akwa Journal of Sociology, Vol. 1 No 1: 1-10 April.

27. Jibril, M (2003) "Nigeria Higher Education Profile". Retrieved from www.bc.ed.u/be.org/avp/soc/cihe/profiles/Nigeria. 30th March 2008.

28. Joint Admission and Matriculation Board (2011) UME/DE BROCHURE, 2012/2013 Academic Session, Lagos: JAMB.

29. Junaid, O (2006) "Unilag Historical Sketches" in Olurode Lai, and Funmi Bammeke (eds) Campus Life, Lagos: John West Publication Pp. 8-19.

30. Jupp, J (1970) "The Discontents of Youths" in Crick, B. (ed) Protest and Discontent, Middle Sex: Pengium Books.

31. Keller, E (1983) "The State, Public Policy and The Mediation of Ethnic Conflict" in Donald Rotchild and Victor Olorunsola (eds), State Versus Ethnic Claims: African Policy Dilemmas, Boulder: West View Press.

32. Kosemani, J.M. and Orubite, A.K (1995) History of Nigerian Education: A Contemporary Analysis. Port Harcourt: Abe Publisher.

33. Liket, R (1961) New Pattern of Management, New York: McGraw-Hill Book Company.

34. Lipset, S.M (1971) Rebellion in the University. Boston: Little Brown \& Co.

35. Merton,R.K(1968) "Social Structure and Anomie" in Merton's Social Theory and Social Structure (enlarged edition) New York: The Free Press,Pp185-214

36. Mohantey, D.K (1999) Higher Education and Student Politics in India, India: Anmol Publication SPVT Ltd.

37. Nkinyangi, J.A (1991) "Student Protests in Sub-Sahara Africa". Journal of Higher Education, Vol. 22, No 2: 157-173.

38. National Teacher Institute, NTI (2005) Historical Foundation of Education, Kaduna: NTI, Nigeria

39. Nwagwu, N.A (2005) “Crisis in the Nigerian Education System”. A key note address, National Conference of the World Council for Curriculum and Institution at the Unicersity of Lagos. 
40. Nwideeduh, S.B (2003) "The Development and Administration of Nigeria University 1948-1993: An Overview" in S.B. Nwideeduh (ed) Trends and Issues in Managing Universities in Nigeria, Owerri: Spring Field Publisher Ltd. Pp. 1-44

41. Ofordile, C (2001) "Crises and Challenges in Higher Education in Developing Countries, Students Factor: Cultism. In A.U. Akubue and D. Enyi (eds), Crises and Challenges in Higher Education in Developing Countries, A Book of Readings. Ibadan: Wisdom Publishers Ltd. Pp 309-317.

42. Ogundele, O.J. and Okonji P.S (2004) "Comparative Management and Administration: An Overview" in O.J Ogundele (ed) Comparative Management and Administration: A Book of Reading, Ibadan: Heinemann Education Books (Nigeria) Plc Pp15-31.

43. Ogunyomi A (1994) "Students' Unrest and University Governance under the Military": A case study of Babangida Years, in Bello-Immam I.B. University Governance in Nigeria. Proceedings of the 8th General Assembly of the Social Science Council of Nigeria, Ibadan: The Social Science Council

44. Ojo,J.B(1995) Students Unrest in Nigerian Universities: A Legal and Historical Approach, Ibadan: Spectrum and Institute for Research in Africa.

45. Okebukola, P (2006) "The State of Nigerian University" in Borishade, B and Okebukola, P (eds) Repositioning Higher Education in Nigeria. Ibadan: Heinemann Education Books (Nigeria) Plc Pp 24-79.

46. Olamosun, B (2000) Crisis of Education in Nigeria. Ibadan: Book Farm Publisher.

47. Omole, $P$ (1995) “Managing Students' Crises in Nigeria Institution of Learning” In E. Okpema (ed) Education and Stability: A Book of Reading, Ibadan: Association for Promoting Quality Education in Nigeria.

48. Onwurah, C.U (2000) “Towards Effective Management of Students' Crisis in Tertiary Institution", Nigerian Journal of Empirical Studies in Psychology and Education, Vol. 1 No 2: 1-10, March.

49. Onyenoru, I.P (1996) Nature and Management of Students' Conflict. Ibadan: Sociology Series No. 4, Department of Sociology, University of Ibadan.

50. Rosenthal, U., Charles, M and Hart, P (1989) Coping with Crises: The Management of Disaster, Riots and the Terrorism; Springfield, IL: Charles Thomas Publishing Company

51. Salami, A.A (2004) "Nigerian Student and Campus Cults: Quest for Recognition", The Polymath, Journal of the Moshood Abiola Polytechnic, Abeokuta: Vol. 1, No. 2 : 75-87.

52. Sanda A.O (1992) Managing Nigerian Universities, Ibadan: Spectrum Book Limited. Chapter 4 Pg 34.

53. Schmid P.A (2000) Thesaurus and Glossary of Early Warning and Conflict Prevention Terms. Princeton: Princeton University Press.

54. Smith, E.A (1962) American Youth Culture. Glencoe: The Free Press.

55. Stoner, J and Freeman, E (1989) Management, (4th edition), Englewood Cliffs, N.J: Prentice Hall.

56. Sugarmam, B (1967) "Involvement in Youth Culture, Academic Achievement and Conformity in School” British Journal of Sociology, XVIII: 151-164. 
57. Taiwo, O (2004) "An Appraisal of the Use of Threat or Violence in Resolving students' Crisis in our Universities" in Lai Olurode and Omololu Soyombo (eds) Reading in Campus Violence, Lagos: John West Publication Ltd. Pp 237-256.

58. Thomas, K.W. (1976) "Conflict and Conflict Management" in M. Dunnette (ed) Handbook of Industrial and Organizational Psychology, Chicago: RandMc Nally.

59. Tosi, H.L, Rizzo, J.R and Carrol, S.J. (1986) Organizational Behaviour, New York: Xicom

60. William, S., Harnet, T., and Strassner, E (2003) "Higher Education in Nigeria: A Status Report" Higher Education Policy, 16: 259-281.

61. Wiseman, J (1986) "Urban Riots in West Africa 1977-1985" Journal of Modern African Studies, 24, 3: 509-578.

62. Wokocha, A.M (1997) "The Menace of Secret Cult Activities in the Nigerian School System". Delta Journal of Educational Development. 5(1\&2): 72-83.

63. Yinusa, M.A (2005) "Youth and Urban Violence in Nigeria: A Reflection on the Contemporary Ilorin Township" in Alanamu (ed) Issues in Political Violence in Nigeria, Ilorin: Hamson Printing Communication Pp 58-74.

64. Newspapers

65. The Punch, June 17, 2005 (Lagos)

66. The Punch, June 18, 2005 (Lagos)

67. Saturday Punch, May 14, 2005 (Lagos)

68. The Punch, June 17, 2008 (Lagos)

69. The Guardian, June 17, 2005 (Lagos)

70. Daily Trust, April 3, 2012(Abuja)

\title{
Summary
}

\section{Students' Crisis in Nigerian Tertiary Educational Institutions: A Review of The Causes and Management Style}

\author{
Ajibade David \\ Kogi State University, Anyigba, Nigeria
}

Students' crisis is one of the challenges confronting Nigerian educational system in the recent past. The level of disruption and closures that has bedeviled Nigerian tertiary institutions is unprecedented in the history of higher education in Nigeria. However, realizing the importance of tertiary education in national development, this paper is conceived to identify the factors responsible for the occurrence of students' crisis and the management style adopted by the individuals and groups involved in tertiary education system. Secondary source of data collection was used in the study. Data were generated from textbooks, published and unpublished materials, including the internet. The data were first of all summarized and then content-analysed. The study revealed factors such as authoritarian governance arising from the erosion of institutional autonomy, poor remuneration of staff who have a major obligation for building moral character and well- 
being of students, cult activities, etc as responsible for students' crisis in Nigerian tertiary educational institutions in the recent past. However, in managing the phenomenon, diverse management style ranging from immediate closure of schools, suspension or dissolution of students union government, expulsion/rustication of students' leaders and the use of security agencies such as the police/army were employed. Such management styles are, however, regulatory, reactive and punitive in nature and it brought about the re-occurrence of the phenomenon. Based on the inappropriateness of such strategies, the study recommended a new management style that will be of immense benefit to both the present and future tertiary institutions administrators in Nigeria.

Keywords: Management style, Students Crisis, Tertiary Institutions, Nigeria. 